\title{
Intermodal Logistics Policies: Where Do We Stand Internationally?
}

\author{
Burkhard E. Horn*
}

\begin{abstract}
This paper defines the emerging intermodal issues, identifies alternative solutions and develops strategies to achieve them. It reviews intermodal logistics policies in the EU, NAFTA and Asia, focusing on the United States and Japan in NAFTA and Asia respectively, because they have been the prominent motors of international trade in their regions. From an Asian standpoint, it is a pity that it is not yet possible to report on a common intermodal strategy.
\end{abstract}

Keywords: Asia, Intermodal, European Union (EU), Logistics, North America Free Trade Agreement (NAFTA).

\section{POLICY CONTEXT}

The development of intermodal freight logistics has become an important policy priority and challenge worldwide. More and more Asian companies and port operators are committed to adopt 'best' and 'advanced' logistics and supply chain practices that are of top world standard. However, intermodal policy settings and approaches differ from country to country and between the major three industrial world regions: Asia, European Union and North America Free Trade Agreement (NAFTA) area.

Logistics and freight transport go hand in hand. Progress in global-by necessity intermodal-logistics is essential in sustaining trade and business growth and, consequently, affects transport and infrastructure policies. To implement an effective global supply chain strategy, a well functioning maritime and air transport system with adequate land access is required.

The question is in essence, how can developments-and new strategies and innovations - in intermodal transport streamlined with needs and trends in logistics chains and operations (i.e. ultimately businesses' supply chain management).

Intermodal freight transport can now be considered to constitute the third or fourth most important mode in market share after unimodal road, rail or water/sea transport depending on the country or region concerned. However, what has been lacking in policy and practice is the acceptance of a holistic approach to the intermodal transport system, seen as one entity. Moreover, there is the increasing weight of requirements to assure long-term sustainability in the transport sector. Environmental

- Counsellor and Visiting Fellow, Institute for Transport Policy Studies, 3-18-19 Toranomon, Minato-ku. Tokyo, 105-0001, Japan E-mail: horn@jterc.or.jp 
concerns and growing highway congestion call for new innovative initiatives to promote the optimized use of the entire multi-modal transport system.

This paper is part of an overall research initiative to define the emerging intermodal issues, identify alternative solutions and develop strategies to achieve them. It reviews intermodal logistics policies in the EU, NAFTA and Asia, focusing on the United States and Japan in NAFTA and Asia respectively, because they have been the prominent motors of international trade in their regions. From the Asian standpoint, it is of course a pity that it is not yet possible to report on a common intermodal strategy.

\section{DUAL SYSTEMS APPROACH}

\section{Definition of Intermodal Logistics}

As part of integrated advanced logistics and supply chain management, intermodal freight logistics focuses on and is defined in terms of seamless door-to-door freight transport operations using at least two different modes of transport. In general the initial and/or terminal portions are short and by road and the main long haulage of containers, swap bodies, trailers or trucks is by rail, waterway, sea or air.

This concept ${ }^{2}$ is built on the following key notions:

- door-to-door transport ${ }^{3}$

- two or more transport modes - in essence road (truck), rail, water, air

- seamless operation (i.e. predominant use of intermodal containers, swap bodies, etc., and no handling of the goods themselves in changing modes).

\section{Two Goals}

As depicted in Figure 1, an intermodal freight logistics strategy must pursue two system views focusing on

- optimizing the supply chain and linkages between the partner companies, and

- optimizing the use of the multimodal transport system-modal shifts

and it should aim at reconciling both goals.

\footnotetext{
2 See ECE, ECMT, EU, OECD

${ }^{3}$ Either carried out by one 3PL or mega logistics provider, or through a coordinated chain of multiple mode or area specific logistics providers
} 
Figure 1. Dual systems view of intermodal freight logistics

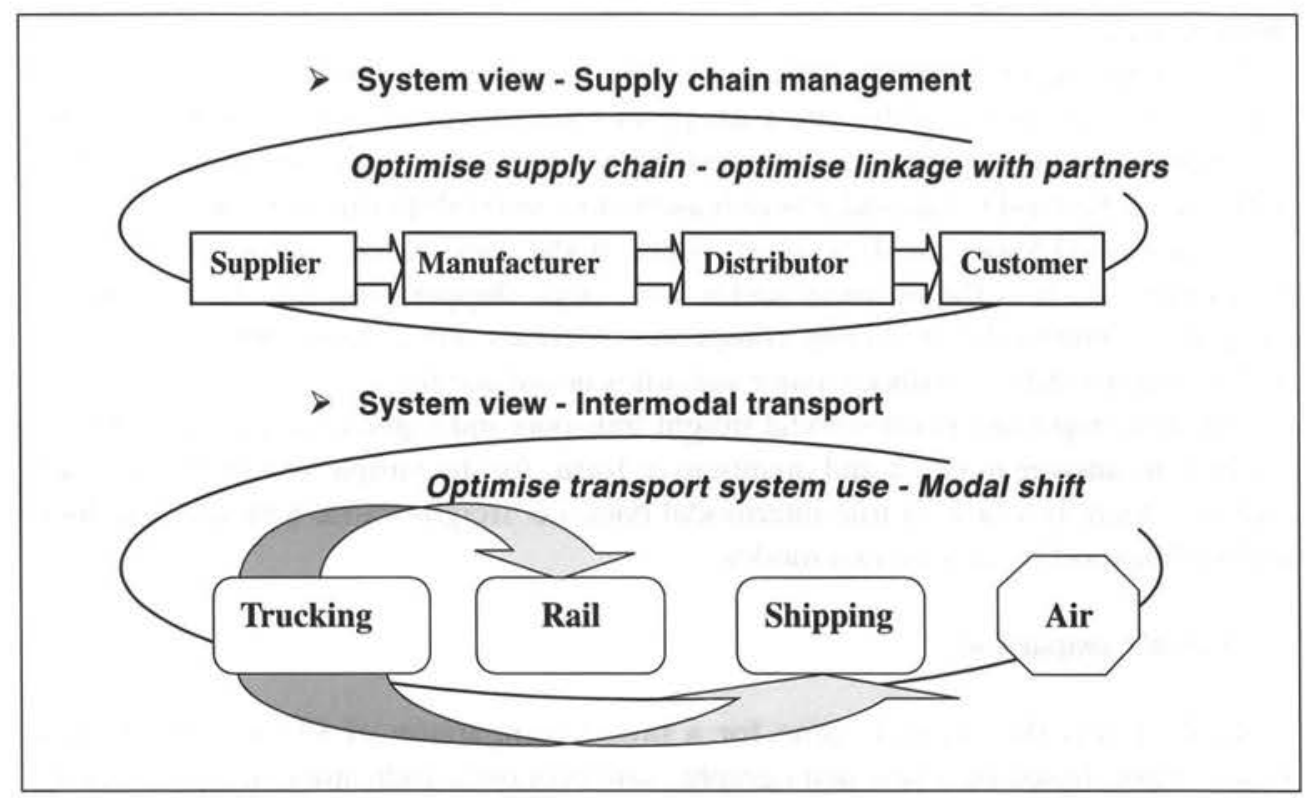

Intermodal logistics is part and parcel of today's (global) supply chain and businesses' supply chain management (SCM) process. Therefore in launching research in this field and implementing ultimately successful intermodal logistics schemes, the starting point should be foremost businesses' needs and demand.

The government's role is to assume administrative guidance in a number of sectors, such as provision of infrastructure and network investments, IT and communications, regulations, trade facilitation, customs, support for SME's, etc. From an institutional perspective, and to reconcile private interests with public and social goals, a new breed of intermodal governance and institutional structure need to be developed.

While an intermodal systems view should be the basic reference, modal policies continue to be necessary to build missing links, eliminate bottlenecks and improve inefficient connections between modes. Even when pursuing intermodal objectives through modal shifts from trucking to rail or coastal shipping, mode specific capacity and/or service improvements have to be envisaged. Rail, shipping and trucking are competitors, but they are also partners in door-to-door intermodal operations.

\section{INTERMODALISM IN THE TRIAD}

\section{Differing Policy Views}

In Asia, countries-and Japan is no exception-have been concentrating on developing, building and operating their unimodal transport systems, and therefore 
have only recently started to recognize the need for an overall intermodal transport policy which serves the international and Asian freight flows and domestic modal shifts as well.

In Europe the prevailing tendency is to try to force intermodal policies through a top-down approach led by the European Commission. Several EU Member governments and in particular Switzerland are pursuing strategies to shift freight traffic from the road to rail and where feasible to coastal shipping and waterways.

In the United States, on the contrary, inter-modal, land-based transport is driven by the market and it is the business sector with large shippers and integrators, railway companies, intermodal marketing companies, logistics service providers, etc. that has pushed intermodal use without major subsidies or outside force.

But how important is intermodal freight transport and logistics in practice? This is not easy to answer in exact and quantitative form, for the simple reason that in most countries there is a lack of true intermodal data; i.e. freight traffic tonnages for doorto-door transport by at least two modes.

\section{Overall Comparison}

Table 1 sets the general scene for a broad comparison of EU-154--the United States--Japan based on a few demographic and economic indicators, and presents the respective overall road, rail and water freight transport statistics.

From the official tonne-kilometre data shown in the Table the rather weak or very weak role of rail transport in Europe and Japan is apparent. Rail in the U.S. seems to do well currently.

Table 1. Some basic indicators EU-15-U.S.-Japan

\begin{tabular}{l|r|r|r}
\hline & EU & U.S. & Japan \\
\hline \hline Population (millions) & 379 & 278 & 127 \\
\hline Area (million sq km) & 3.24 & 9.4 & 0.38 \\
\hline GDP (\$bn in PPP’s) & 9,593 & 10,143 & 3,364 \\
\hline Exports (\$ bn) & 936 & 1,019 & 402 \\
\hline Imports (\$ bn ) & 1,023 & 1,301 & 348 \\
\hline Road freight (bn tonne $\mathrm{km})$ & 1,329 & 1,499 & 307 \\
\hline Rail freight (bn tonne $\mathrm{km})$ & 243 & 2,093 & 23 \\
\hline Inland shipping freight $($ bn tonne $\mathrm{km})$ & 1,395 & 1,025 & 242 \\
\hline
\end{tabular}

Sources: ECMT, EU, OECD

4 European Union with 15 Member countries 


\section{Modal Split}

Table 2 presents official modal split data.

There is relative over reliance on trucking especially in Japan and also in Europe. Short sea shipping (SSS) in the U.S. seems to be lagging behind, while inland waterways are quite well used.

Table 2. Modal split (\%, t-km) EU-15-U.S.—Japan

\begin{tabular}{l|r|r|c}
\hline & EU & U.S. & Japan \\
\hline \hline Road & 43.8 & 30.0 & 53.7 \\
\hline Rail & 8.1 & 38.2 & 4.0 \\
\hline Inland waterways & 4.1 & 9.4 & \\
\hline Coastal sea & 41.3 & 7.4 & 42.3 \\
\hline Pipelines & 2.8 & 15.0 & \\
\hline
\end{tabular}

Sources: U.S.-BTS, EU, MLIT 1999/2000

\section{Intermodal Freight Share}

The share of intermodal transport is assessed in Table 3 using different sources. According to the official European statistics and the estimated U.S. data, 'intermodal' rail is between one fourth and one fifth of total rail traffic. The U.S. freight rail system provides the intermodal 'landbridge' operation across the country and is an essential intermodal link for international trade serving the seaports as the major container gateways.

The Japanese data emerge from an ad hoc survey in 2000 covering certain commodities transported domestically for a very limited period (three days), distinguishing 'road only' and 'road and sea or rail' in detail. Based on the survey, half of rail traffic is intermodal using mostly 12 feet containers standardized by Japan Railway, though overall rail share is quite low, i.e. around $4 \%$. Owing to the geographical situation, Japan has a high water/sea share, most of which is not intermodal, but water/sea only. 
Table 3. Intermodal freight transport shares EU-U.S.—Japan

\begin{tabular}{l|c|c|c}
\hline & $\begin{array}{c}\text { Total } \\
(\boldsymbol{\%})\end{array}$ & $\begin{array}{c}\text { Water/sea } \\
(\boldsymbol{\%})\end{array}$ & $\begin{array}{c}\text { Rail } \\
(\boldsymbol{\%})\end{array}$ \\
\hline \hline EU-15 in t-km & 8.6 & 15.6 & 25.9 \\
- Germany in t & & & $>10.0$ \\
- Netherlands in t & 8.0 & 24.0 & 24.0 \\
- U.K. in t & 20.0 & 22.0 & 13.0 \\
& & & \\
\hline U.S. in t-km & & & $19.0-30.0$ (a) \\
\hline Japan in t (b) & 1.5 (c) (d) & 7.9 & 50.0 \\
\hline
\end{tabular}

(a) $30.0 \%$ if automobile transport on rail (around $11 \%$ ) is included;

(b) According to an ad hoc 3-day survey for tonnes domestically transported in $2000,82.9 \%$ is 'road only';

(c) 'road and sea (container ship, ferry and RORO)' is $1.0 \%$;

(d) 'road and rail (container train only)' is $0.5 \%, 1.0 \%$ if conventional freight trains are included.

\section{POLICY DEVELOPMENT}

\section{Policy Development Process}

In reviewing the EU, U.S. and Japanese policy statements, we find a high degree of communality. Their transport policies are formulated within a general policy framework aiming at sustainable development (i.e. economic growth and socio/environmental progress with global competitiveness as a primary goal).

Within this framework, the rationale of intermodalism requires a 'seamless' 'integrated' transport network. It aims at a balanced, "optimum", use of the total freight logistics system. Note however intermodal transport and logistics policies are not solely confined to modal shift actions (e.g. diverting freight traffic off the road to other surface modes). Intermodal policies also involve measures that enhance the interconnectivity and interoperability of networks. 
Figure 2. Policy development process

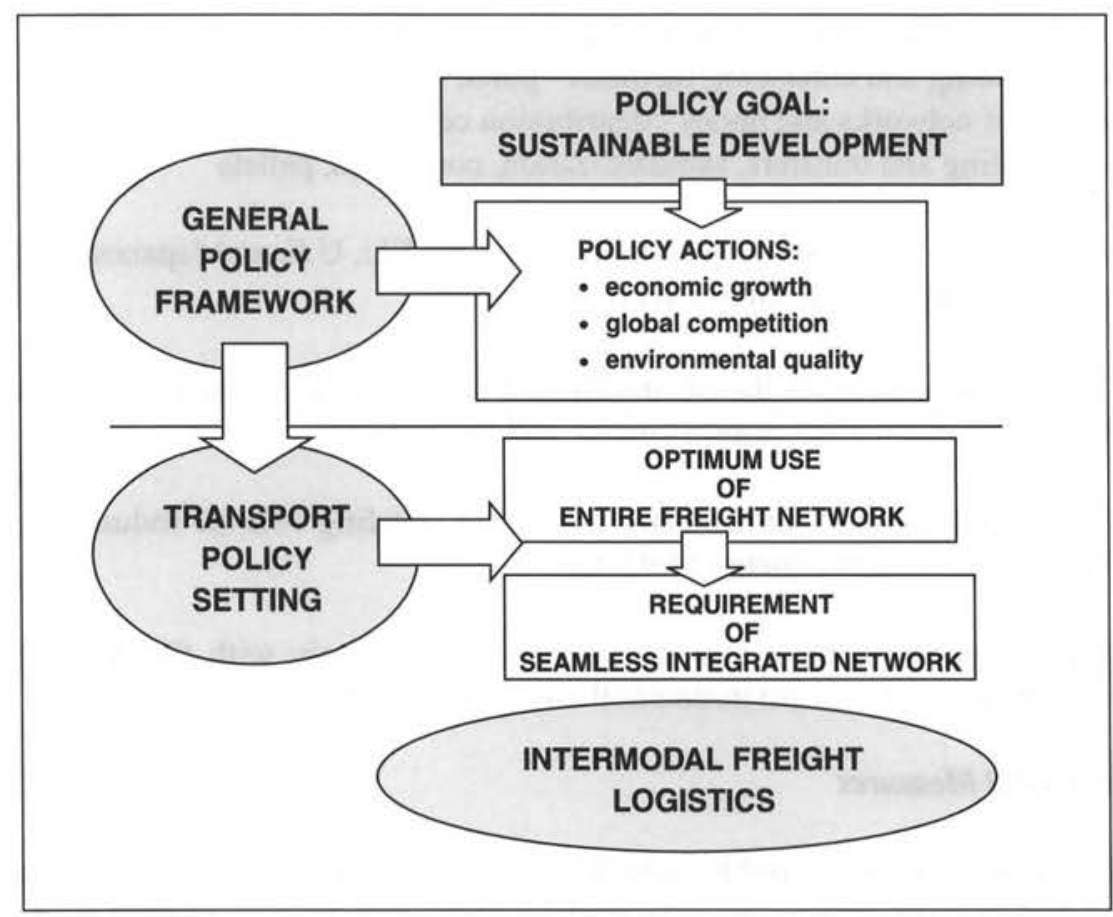

Policy directions and goals

Directions and goals of intermodal freight logistics policies can be summarized as follows:

- Global competitiveness and connectivity

o global, intermodal logistics

o ports, international routes and corridors, border crossings

o seamless sea/air - rail/waterways - road connections and transfers

o infrastructure, IT, procedures, customs

- Support/incentives for businesses' supply chains

o intermodal business logistics

o industry location, deregulated zones, taxation, access

o infrastructure, cargo hubs, intermodal connectors

o technology, IT, wireless, EDI, innovations

- Sustainability - reduce environmental burden ...attenuate road congestion

o corridor, city, intermodal logistics

o land use planning - network design

o transport systems and operations management 
- Integrated, intermodal transport system-towards seamless operations, optimum use of networks - modal shift

o regional, national, intermodal logistics, combined transport

o providing and enhancing facilities - ports, intermodal terminals

o use of networks and nodes - distribution centers, access

o handling and transfers, standardization, containers, pallets

Overall policy directions as they appear from the EU, U.S. and Japanese directives and legislations are similar, although emphases differ

- EU's main concern is the environmental issue, highway congestion, "external" costs, and technology improvements and innovations

- U.S. stress global connectivity and trade, leading role of industry, market treatment of modes, energy problem

- Japan's policy aims at competitiveness, increasingly with the Asian-Pacific market in mind, and environmental and societal needs

\section{Intermodal Measures}

Both market forces and public authorities are called upon to further develop these policies and to work on specific intermodal actions and projects as well as the most efficient implementation strategies.

In general, intermodal logistics policies will comprise a combination of actions. Figure 3 presents an overview of the variety of intermodal policy instruments and measures. As in all innovative economic sectors, the role of 'Research and Development' can be very important.

Figure 3. Combination of economic, technical and regulatory intermodal measures

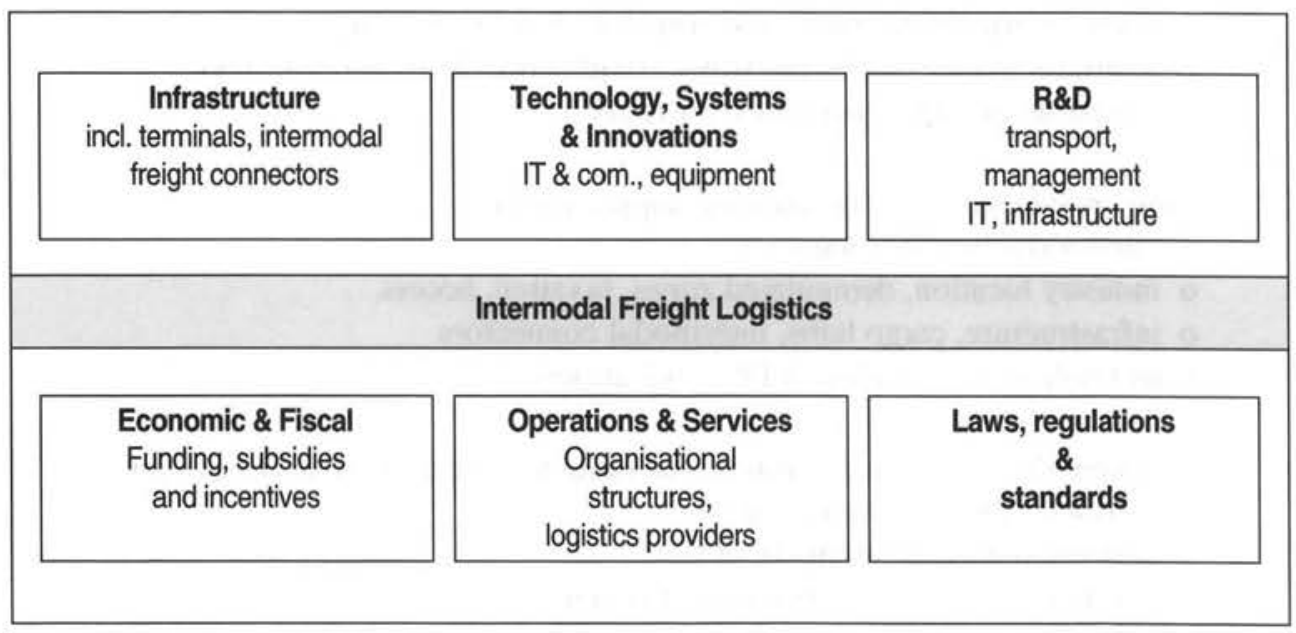


The government's (administrations') interventions should primarily aim at assuring a level playing field for the market and adapt regulations accordingly, provide a coherent transport and logistics network of routes, corridors, ports, airports and terminals and promote its optimized use meeting environmental requirements.

Shippers and logistics providers will be mainly concerned with developing costefficient, and now more and more environment-friendly, logistics schemes and customer-oriented value added services.

The September 11, 2001 terrorist attack added a new priority on security measures that affect logistics procedures and operations. These issues cannot be treated in length in this paper.

\section{POLICY ANALYSIS}

The European, American and Japanese logistics policies have a number of distinct intermodal features. Special programmes have been launched that are worthwhile to review in some detail. As will be seen there are commonalities and differences. But clearly there is an underlying long-term trend towards an intermodal system and intermodal partnership — with all the consequences that such a view may entail.

\section{European Intermodal Policy}

Many European governments emphasize the need for an intermodal transport and logistics policy to combat highway congestion and environmental problems, to increase overall traffic efficiency and profit from benefits of co-ordinating modes. Nine European countries invest yearly about 450 million Euros in intermodal transport. The intermodal transport of containers, trailers and swap bodies has increased by $150 \%$ during the past decade.

The European Commission is a mighty defender and promoter of intermodality ${ }^{5}$ as part of the European Union's Common Transport Policy for sustainable mobility. The policy vision is to develop a structured approach to intermodal freight transport in the framework of a single transport market with advanced harmonisation of regulations and competition rules.

Table 4 summarizes the key elements of the EU's basic intermodal policy as put forward in the Commission's 1997 Communication. The declared goal is to optimize interdependence and complementarities of transport modes.

The EU policy recognizes logistics to be a crucial factor of competitiveness. Taking into account the complex interaction of suppliers, manufacturers, retailers and consumers, intermodality should allow the integration of a broad range of transport services in the supply and distribution chains whereby well functioning information and communication technologies are indispensable.

\footnotetext{
s "Intermodalism" in U.S. terminology
} 
In other words the integration of intermodal transport in supply chains is a key challenge. Noteworthy in this regard are also the emphasis on establishing a uniform intermodal liability regime and the intention to create an electronic commerce market for intermodal freight logistics (E-logistics).

Table 4. Overview of elements of the EU's intermodal policy

\begin{tabular}{|c|c|c|c|}
\hline Infrastructure & Operations & $\begin{array}{c}\text { Technology } \\
\text { R \& D }\end{array}$ & Rules, Standards \\
\hline $\begin{array}{l}\text { Design of intermodal } \\
\text { transfer points }\end{array}$ & $\begin{array}{l}\text { Common charging and } \\
\text { pricing }\end{array}$ & $\begin{array}{l}\text { Interoperable systems } \\
\text { \& equipment }\end{array}$ & $\begin{array}{l}\text { Transport } \\
\text { standards } \\
\text { (esp. load units) }\end{array}$ \\
\hline $\begin{array}{l}\text { Intermodal design of } \\
\text { Trans-European } \\
\text { Networks (TEN) }\end{array}$ & $\begin{array}{l}\text { Freight routes in } \\
\text { intermodal \& } \\
\text { interoperable system }\end{array}$ & IT system, EDI, ITS & $\begin{array}{l}\text { Intermodal liability, } \\
\text { Work regulations }\end{array}$ \\
\hline $\begin{array}{l}\text { Missing links: } \\
\text { Intermodal priority } \\
\text { projects }\end{array}$ & $\begin{array}{l}\text { Value-added logistics } \\
\text { services } \\
\text { (esp. E-logistics) }\end{array}$ & $\begin{array}{l}\text { Satellite based } \\
\text { communication } \\
\text { system }\end{array}$ & $\begin{array}{l}\text { Intermodal } \\
\text { competition rules }\end{array}$ \\
\hline
\end{tabular}

The EU's White Paper (2001) on European transport policy for 2010 proposes to take measures that should make the market shares of the modes of transport return by 2010 to their 1998 levels. The basic policy directions and means are:

- charging and pricing,

- revitalizing road alternative modes, and

- targeted TEN (Trans European Network) investments.

Against the background of a predicted 50\% trucking increase from 1998 to 2010, the basic challenge is to reduce road congestion. The aim is to link up sea, inland waterways and rail and utilize the still untapped capacities of short-distance coastal shipping and inland waterways. One improvement proposal is therefore to develop "motorways of the sea" as part of the Trans-European Network (i.e. shipping links providing bypasses around the land bottlenecks in the Alps and the Pyrenees). Innovative port services and operations are also supported.

Another focus is on testing and implementing innovations in logistics concepts and systems, harmonising and standardising intermodal loading units (pallets, containers and swap bodies) and creating the right technical conditions for stimulating the development of "freight integrators" specialising in the integrated, seamless transport of full loads at European and world level.

As a follow-up to PACT (Pilot Actions for Combined Transport) which terminated in 2001, a start-up initiative for intermodal services is being launched in 2003, the new Marco Polo programme. The aim is to shift freight from the road to other more environment-friendly modes and to improve the operation of the entire intermodal 
chain. The programme supports actions in the freight transport, logistics and other relevant markets to contribute to return to 1998 modal share levels by helping to shift the expected increase in international road freight traffic of 12 billion t-km per year to short sea shipping, rail and inland waterways or to a combination of modes of transport.

The programme aims to support operations and services directly and offers incentives for the industry. It is based on calls of proposals. It is designed to last up to 2010 and has a budget envelope of 75 million Euros. All segments of short sea shipping, rail and inland waterway freight markets are eligible. The three different types of action are presented in Table 5 together with the conditions of funding.

Table 5. Actions and support conditions of EU's Marco Polo programme

\begin{tabular}{c|l|c}
\hline $\begin{array}{c}\text { Modal Shift } \\
\begin{array}{c}\text { Concrete projects \& } \\
\text { operations }\end{array}\end{array}$ & $\begin{array}{c}\text { Catalyst actions } \\
\text { Break-through solutions }\end{array}$ & $\begin{array}{c}\text { Common learning } \\
\text { Better knowledge \& } \\
\text { methods }\end{array}$ \\
\hline \hline Aid to start-up services & $\begin{array}{l}\text { Overcome structural barriers, } \\
\text { innovative character }\end{array}$ & $\begin{array}{c}\text { Co-operation, sharing of } \\
\text { know-how, mutual training }\end{array}$ \\
- 1 Euro subsidy per 500 t-km shifted & -- min subsidy 1.5 Mio \\
- min subsidy 0.5 Mio & Subsidy up to 35\% & $\begin{array}{c}\text {-- min subsidy 0.25 Mio } \\
\text { Subsidy up to 50\% }\end{array}$ \\
- ancillary infrast. 20\% & - ancillary infrast. 20\% \\
$\begin{array}{l}\text { Subsidy up to 3 years, viable } \\
\text { after subsidy }\end{array}$ & $\begin{array}{l}\text { Subsidy up to 4 years, viable } \\
\text { after subsidy }\end{array}$ & Subsidy up to 2 years \\
\hline
\end{tabular}

The concrete modal shift projects would typically consist of new services in the non-road freight market. They should be viable on their own within a period of three years. The catalyst actions are oriented towards new innovative solutions and may tackle existing structural market barriers; they include "motorways of the sea", pools for tri-modally compatible containers, one-stop international freight rail services or intermodal logistics IT systems. Finally the common learning actions would concern exchange of know-how, training, improved procedures at sea and inland ports, adapting transport systems to meet logistics needs, shippers' intermodal understanding and awareness, etc. The results of all these actions will be monitored and experience will be disseminated.

The implementation of intermodal initiatives will also depend on the image of intermodal logistics among shippers and marketing efforts promoting intermodal logistics as a competitive business advantage and as an effective tool in up-to-date supply chain management. A better understanding of shippers of the pros and cons of intermodal logistics operations is often necessary.

A successful example of such efforts has been the Dutch programme of business level logistics scans carried out amongst 100 pre-selected shippers, of originally 600 companies altogether. The aim was to introduce cost-effective intermodal solutions at 
micro level targeting the companies' specific business activities. Based on voluntary, clearly defined contractual agreements between companies and the Ministry of Transport, the scans were financed by $75 \%$ by the government and $25 \%$ by the individual companies. Independent logistics specialists were employed to assess in detail profitable intermodal opportunities in companies; logistics activities and business practices. The results were that 80 companies out of 100 -including many SME's-had a realistic potential to improve their intermodal practice, with often surprising benefits down to transport distances of $150 \mathrm{~km}$ or so.

\section{U.S Intermodal Policy}

The efficient logistics system in the North America is indispensable for the North America Free Trade Agreement (NAFTA) involving the U.S., Canada and Mexico. These three countries are set to harmonize their logistics policies and procedures, and to make the logistics systems interoperable. Indeed there are basically few conflicts of interests among the three countries in integrating the logistics systems concerned Because of the size of its economy and its central geographical location, the U.S. has a factual leadership position and has taken initiatives in enhancing intermodal logistics and transport in the region including cross-border facilitation, in spite of the tightened security situation.

The original milestone of American intermodalism was the Intermodal Surface Transportation Efficiency Act of 1991 (ISTEA'91), which provided the legislative framework to develop "a National Intermodal System that shall consist of all forms of transportation in a unified, inter-connected manner ...". The benefits of intermodalism were expected to be lower transport costs - through the use of the most suitable mode for individual segments of the entire transport chain-increased national productivity and efficiency, more efficient use of existing infrastructure and lower environmental impacts. Some flexibility for intermodal funding was introduced together with the possibility of joint public/private investments. The Office of Intermodalism was created at the highest executive level of the Department.

Nevertheless intermodal transport and logistics was and is largely driven by the industry through its search for least cost solutions. Market deregulation and competition among shippers and carriers reduced the transport-related transaction costs for business. Most of the large shippers and carriers have now corporate units responsible for intermodal transport, logistics or supply chain management.

However, there were and are still a number of impediments to intermodalism:

- inadequate infrastructure to accommodate double stack rail services,

- congestion on access roads serving intermodal terminals and ports,

- operational inefficiencies at terminals, including EDI system usage,

- regulations resulting delays and costs when building new facilities,

- impacts of changes in ship design on ports and intermodal facilities,

- financial bottlenecks both in private and public sectors, and

- institutional constraints—customs, domestic and foreign partner relationships, governmental data requirements. 
In 1998, the Intermodal Surface Transportation Efficiency Act for the 21st Century (TEA-21) was enacted. The challenge was to meet the evolving needs of the private sector that was competing not only in the domestic market place, but also increasingly in the global environment. In particular it was necessary to integrate the accomplishments of NAFTA agreed in 1994.

The expanding trade and investment opportunities had significant impacts on trans-border transport between the three countries, and raised challenges specifically for intermodal operations. Intermodal rail has a clear advantage at border crossings; while trucks have to queue up for inspections and clearance, trains can be prechecked and electronically tracked passing at full speed.

The U.S. transportation policy itself is best summarized in a statement of the former Transportation Secretary Rod Slater (Feb 1997- Jan 2001): “...to produce a safe and sustainable transportation system that is international in reach, intermodal in form, intelligent in character and inclusive in service."

Table 7 summarizes the essential elements of the U.S intermodal policy. Note the basic philosophy of the U.S. intermodal policy:

- Intermodal is industry and market driven, and

- Government acts as a convener and catalyst, i.e. few public sector interventions, few governmental initiatives.

Table 7. Overview of elements of intermodal policy in the U.S.

\begin{tabular}{|c|c|c|}
\hline Strategy & Infrastructure & Technology \\
\hline - Freight facilitation strategy & $\begin{array}{l}\text { - NHS intermodal freight } \\
\text { connectors }\end{array}$ & $\begin{array}{l}\text { - ITS intermodal freight } \\
\text { program }\end{array}$ \\
\hline - Freight partnerships & - Intermodal cargo hubs & - Intermodal border \\
\hline - Intermodal freight capacity & & clearance \\
\hline $\begin{array}{l}\text { - Freight analysis decision } \\
\text { framework }\end{array}$ & $\begin{array}{l}\text { - National corridor } \\
\text { development }\end{array}$ & $\begin{array}{l}\text { - Standards, "size \& } \\
\text { weight", containers }\end{array}$ \\
\hline - R\&D & $\begin{array}{l}\text { - Co-ordinated border } \\
\text { infrastructure program }\end{array}$ & \\
\hline - Education \& training & & \\
\hline
\end{tabular}

Within this overall policy two targeted programs deserve special mention:

- NHS ("National Highway System") intermodal freight connectors; and

- ITS intermodal freight program.

As part of TEA-21, NHS freight connectors (i.e. public roads leading to seaports, airports and major intermodal terminals) were assessed by the Department of 
Transportation. The aim was to see how land access to U.S. intermodal cargo hubs could be facilitated. Ultimately, connectors to 517 freight terminals-port, rail, pipeline - and 99 major freight airports were identified for enhancement and improvement, altogether 1222 miles in length.

Funding up to 2001-02 was about US\$ 1.5 bn through federal, state, local and private sources. The new draft federal legislations starting in 2004/2005 foresee a funding level of US\$ $3 \mathrm{bn}$. Co-funding selection criteria are shown in Table 8.

Table 8. Co-funding selection criteria for intermodal connectors

\begin{tabular}{l|l}
\hline Airports & 100 trucks/day in each direction or \\
& 100,000 tons/year arriving or departing \\
\hline Ports & $>50,000$ TEU's/year, \\
& 500,000 tons bulk /year or \\
& 100 trucks/day in each direction \\
\hline Rail terminals & $>50,000$ TEU's/year or \\
& 100 trucks/day in each direction \\
\hline Pipelines & 100 trucks/day in each direction \\
\hline
\end{tabular}

A few spectacular intermodal projects-Alameda, Maine, Washington State, New Jersey, New York City-were also undertaken. The Alameda Corridor is a project of national significance serving the ports of Long Beach and Los Angeles, major gateways for Asian trade. The ports, the railway companies and multiple public authorities joined to finance and build the 20-mile grade-separated intermodal freight rail corridor from the ports to the inland intermodal rail yards. The operations of three freight rail lines were concentrated and streamlined and local trucking between ports and rail facilities was reduced. 200 railway grade crossings were eliminated and congestion, air and noise pollution decreased. The US\$2.4 billion project was financed through a private/public partnership by bonds (i.e. railway container charges) and a mix of local, port, state and federal grants and loans.

The second initiative concerns the improvement of intermodal freight operations through an increased use of information technology and ITS-Intelligent Transport Systems. The aim is to enhance the reliability, responsiveness and security of the intermodal freight system. Opportunities to accelerate the application of ITS to intermodal freight movements are investigated including operational tests and demo projects. These center on the development of an ITS architecture and standards, especially for freight identification technologies to ensure interoperability and security controls.

Intermodal freight applications of ITS aim at:

- Supply chain management (e.g. door-to-door shipment);

- Node management (e.g. rail terminal, port, and airport management); and

- Link management (e.g. tracking and asset management of trucks chassis, rail equipment, vessels). 
Figure 4 presents the focus areas for ITS intermodal developments. With the increased pressure for supply chain logistics and just-in-time deliveries, public/private collaboration is warranted to stimulate efficiency and innovation in the intermodal freight transport process. It is needless to say that the September 2001 terrorist act has added a dramatic requirement for security controls and precautions to be taken in the freight industry. IT and ITS technologies can deliver both efficient and reliable control means. International co-operation and standardization are clearly necessary.

Figure 4. Three action levels for ITS/Intermodal freight initiatives

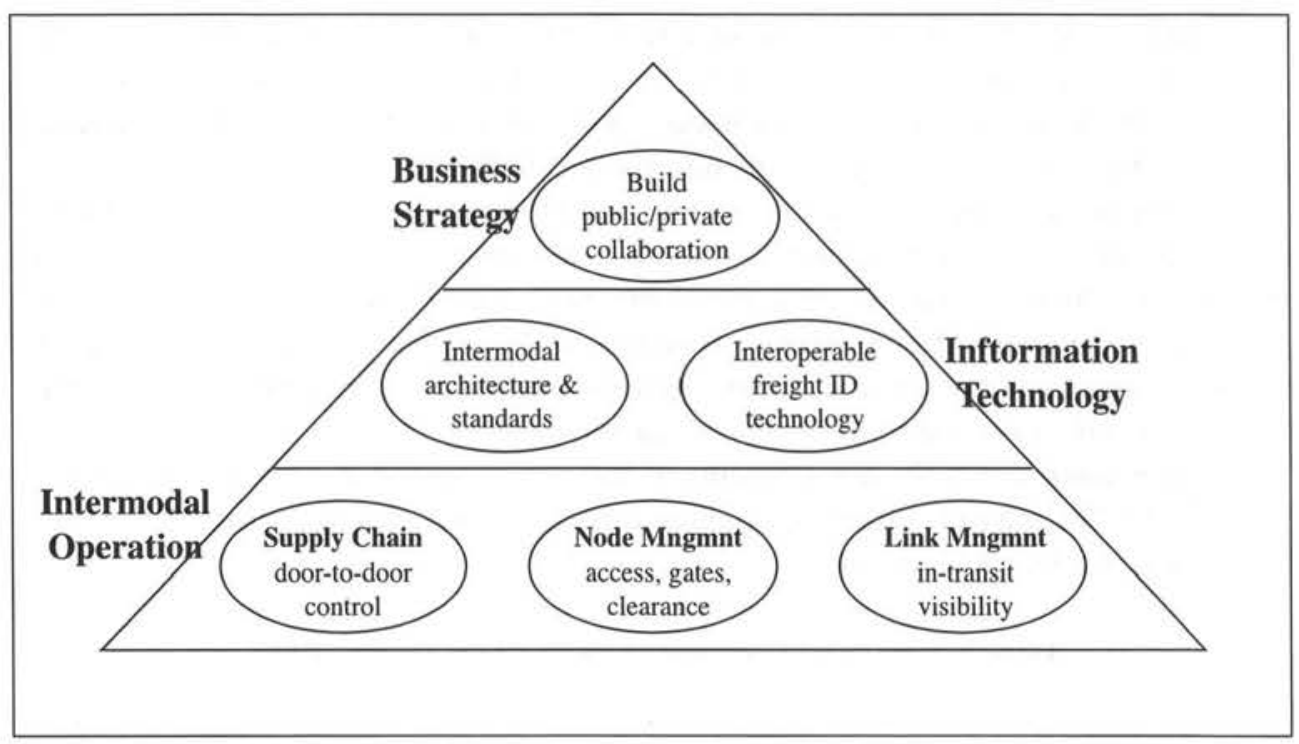

Source : DOT, Office of Intermodalism

To conclude, the U.S. executive and legislative bodies are discussing the renewal of the next long-term transportation legislation-called SAFETEA, i.e. the Safe, Accountable, Flexible and Efficient Transportation Equity Act. Several different drafts of the forthcoming legislation have been put forward and, as usual, discussions about funding and taxation are at the forefront.

Broadly speaking, freight mobility, global connectivity, security and border infrastructure are amongst the priority goals. Also, emphasis is on domestic short sea and waterway shipping. When the final version of this legislation is enacted in 2004, it is likely that these broad policy goals will have been maintained.

\section{Japanese Logistics Policy}

In Asia bi- and multilateral talks have started to reach gradually a number of Free Trade Agreements (FTA). The major challenges are custom duties and other trade barriers such as quantitative restrictions. The issue of the logistics system in the region is rarely touched upon yet, even though Asian countries, mostly separated by 
sea, are in a basically advantageous position to establish an efficient and environmentally friendly intermodal logistics system.

According to an OECD report prepared by an Asian Task Force and published in 2003, several countries, with Singapore, Korea and Japan at the forefront, have crafted comprehensive logistics policies. Most of the Asian countries, however, have mode specific freight transportation policies, while Malaysia and the Philippines explicitly refer to the importance of intermodality. Clearly, it will take some time to have a region-wide intermodal logistics policy in Asia. This paper has therefore concentrated on reviewing Japanese logistics policies as an Asian case study.

About the same time as EU's intermodality communication, the Japanese Government decided on the "Comprehensive Program of Logistics Policies". The goal was to strengthen competitiveness by promoting integrated logistics. Note, as such, Japan does not have an "intermodal" policy per se, but clearly there are many elements and features that address the intermodal challenge.

The Japanese program is rich in content and proposes a wide range of actions and improvements. It was designed to enhance and strengthen Japan's national and international logistics base to offer one of the most convenient and attractive logistics services in the Asian-Pacific region. Business and industry should be able to profit from efficient logistics services and the general public should benefit from improved environmental and social framework conditions.

Table 9 summarizes the key elements of this policy agreed at a Cabinet meeting in April 1997. The measures focused on infrastructure improvements, regulatory reform, innovation and business practices.

Table 9. Overview of elements of Japan's 1997 logistics policy

\begin{tabular}{l|l|l|l}
\hline Infrastructure & Deregulation & Innovation & Business practices \\
\hline \hline - Co-operation between & - Less government & - IT applications & - Better use of work \\
modes & interventions & computerization & resources \\
- Elimination of & - Simplifying & - Standards, EDI, codes, & - Logistics \\
bottlenecks & regulations & pallets containers & management \\
- Development of & - Facilitation to enter & - GPS & - Pricing mechanism \\
international hubs & logistics market & & \\
- Development of & - Abolishment of & - ITS & - SCM \\
$\begin{array}{l}\text { intermodal terminals- } \\
\text { ports, harbors, airports }\end{array}$ & $\begin{array}{l}\text { demand/supply } \\
\text { regulation }\end{array}$ & & \\
- Strategic logistics & & - New transport & - E-com \\
outlay & & technologies & \\
\hline
\end{tabular}

Three levels of logistics systems were distinguished, each involving a number of intermodal elements:

- city logistics - rationalizing door-to-door deliveries, use of railway and inland waterway, waste logistics, improved terminal transport; 
- regional logistics - modal role-sharing, promotion of coastal shipping and related equipment, promotion of rail cargo, access roads to other modes; and

- international logistics - container terminals and cargo handling, import/export procedures; domestic land transport of marine containers and larger semitrailers, expansion of domestic coastal shipping; promotion of competitive international sea and air cargo transport.

In July 2001, the "New Comprehensive Program of Logistics Policies" was issued to take stock of experience and achievements so far and to update aims, targets and measures against the background of the changing situation worldwide, in the Asian hemisphere and domestically. The general orientation of the program was realigned towards an internationally competitive logistics market and system emphasizing cost and environmental dimensions. The ways and means are: better co-operation and partnerships between logistics stakeholders; a fair and competitive logistics market; and the enhancement of logistics infrastructure.

The rather unique feature of the Japanese policy is setting quantitative targets to allow the control of measures and the monitoring of results achieved. Table 10 provides a summary of some results of the 2001 logistics policy as published in the 2002 and 2003 follow-up reports.

Table 10. Japanese logistics policy targets and achievements so far

\begin{tabular}{l|c|c|c}
\hline \multicolumn{1}{c|}{ Target indicator } & Base & Aim & Results \\
\hline \hline $\begin{array}{l}\text { Modal shift to rail \& } \\
\text { coastal shipping }\end{array}$ & $1996: 43.4 \%$ & $2010: 50 \%$ & $\begin{array}{l}2000: 39.6 \% \\
2001: 38.6 \% \\
2002: 3 \text { or } 4 \text { days }\end{array}$ \\
$\begin{array}{l}\text { Time ship arrival_cargo } \\
\text { ready for port exit }\end{array}$ & $1998: 3.6$ days & $2005: 2$ days & $2003:$ air $56 \%$, \\
$\begin{array}{l}\text { \% of airports \& ports } \\
\text { reached in 10 min from } \\
\text { highway }\end{array}$ & $2001:$ air $46 \%$ & $2015: 90 \%$ & port $39 \%$ \\
Palletized ratio of cargo & $2001: 77 \%$ & $2005: 90 \%$ & $2002: 77 \%$ \\
\hline
\end{tabular}

A modal shift action programme was launched by Ministry of Land, Transport and Infrastructure (MLIT) in 2003-04 with the principal aim of reducing $\mathrm{CO}_{2}$ emissions of trucking. So far fifteen intermodal projects are being implemented by consortia of modal and logistics operators and industrial companies whereby one third of the costs are subsidized by the government. The projects are focusing on the freight market that is over a $500 \mathrm{~km}$ radius. 


\section{POLICY IMPLICATIONS}

The comparative policy review presented in this paper shows that we can indeed learn from policies and experience in other regions.

\section{Policy Indicators}

To benefit from more detailed international analyses of intermodal projects and actions, it would be worthwhile to select and assemble data on a few global logistics indicators for monitoring and benchmarking, focusing on key features of intermodal logistics. This could be effectively done through the network of international organizations active in global trade and transport, and now security as well, for which an enormous amount of data are being collected and exchanged.

\section{Policy Awareness}

A better public awareness of the sustainability issue - as treated in the Kyoto agreement - should help to prepare a fertile ground for more co-operation among stakeholders and at the same time expanding the intermodal share. Green logistics management has been adopted by a number of European transnational corporations, such as BASF in Germany and Unilever in the Netherlands, and the recently adopted eco-certification system in Japan for medium and small sized enterprises is a good example.

It is now generally accepted that a decision making process on public policies be transparent, so that stakeholders can understand and support them. This is also the case with intermodal logistics policies. In order to successfully implement the policies, shippers and logistics service providers should be aware and appreciate the value of policy goals and measures.

In this respect the EU provides some useful information. EU studies demonstrate what kind of social cost savings may accrue from the use of intermodal freight transport and logistics. The following figures are evidence of the merit of intermodality:

- Intermodal freight transport results in 60-80\% lower accident figures and 40-50 $\%$ lower $\mathrm{CO}_{2}$ emissions than road transport;

- Overall social cost saving is 33-72\% compared to road transport; and

- 1 Euro external cost saving for $85 \mathrm{t}-\mathrm{km}$ shifted from road to rail, for $52 \mathrm{t}-\mathrm{km}$ to inland waterway, for $50 \mathrm{t}-\mathrm{km}$ to coastal shipping.

\section{Policy Emphases}

The assessment of intermodal policymaking in the triad, shows that the policy intentions pursue the same broad directions:

- efficiency: global competitiveness, supply chain logistics through seamless intermodal door-to-door operations, 
- sustainability: environmental and societal enhancement through the improved use of the multi-modal transport system, and

- innovation: systematic applications of advanced technologies and innovation in intermodal facilities and operation, emphasis on international standardization.

It is notable that there is strong common worldwide interest in standardization, especially standardizing load units, containers, pallets. The EU has now proposed a European intermodal loading unit (EILU), a unit optimized for the transport of pallets, and similar developments are going on in Japan. The EU estimates that the number of road vehicles required to transport the same amount of goods would be reduced by about $25 \%$, if all fully loaded ILU's were to be replaced by fully loaded EILU's.

Although overall policy directions are similar, emphases differ:

- EU's main concern is the environmental issue, highway congestion, and technology improvements and innovations;

- U.S. stress global connectivity and trade, leading role of industry, market treatment of modes, and energy problem; and

- Japan's policy aims at competitiveness, increasingly in the Asia-Pacific market, and environmental and societal needs.

In the face of growing road congestion and more stringent environmental standards, many policy makers in different countries have decided to favour modal shifts diverting trucks off the road.

Table 11. Goals of intermodal logistics

\begin{tabular}{l|l}
\hline EU & $\begin{array}{l}\text { Move towards rail and coastal shipping (back to 1998 modal share in 2010) } \\
\text { Move 12 billion t-km off the road every year (Marco Polo programme) }\end{array}$ \\
\hline U.S. & $\begin{array}{l}\text { Funding intermodal connectors and associated facilities } \\
\text { Developing major intermodal cargo hubs }\end{array}$ \\
\hline Japan & $\begin{array}{l}\text { Targeted 50\% share for rail and coastal shipping in 2010 from today's 39\% } \\
\text { Non-road transport in city \& regional logistics }\end{array}$ \\
\hline
\end{tabular}

As to direct or indirect emphasis on modes, the development of short sea shipping and, as far as possible, waterways is a clear priority, with the U.S. currently in a less advantaged situation with a $7.4 \%$ t-km share compared to EU's $41.3 \%$ for coastal shipping or Japan being in the $42 \%$ range. The U.S. is targeting the short haul intermodal potential and is at the same time assessing the changes needed in their port and vessel fleet structures, especially should the Panama Canal be up-graded to be used by larger vessels. In Japan port structures are being expanded to re-establish competitiveness vis-à-vis other container ports in the Asia-Pacific region.

Concerning railways, the intermodal situation in the U.S. is far superior to that of Japan and Europe. European countries are increasing their funding levels (albeit 
predominantly for passenger rail), while JR Freight is concentrating on certain express routes and niche markets.

\section{Policy Instruments}

In comparison, the intermodal logistics policies of the EU, the U.S. and Japan favour different policy instruments:

- The EU is focusing on operations and services (including subsidies) and has emphasized technology developments and innovations through its large Framework Research Programmes;

- The U.S. at the federal level is using co-funding mechanisms to stimulate intermodal infrastructure projects, Freight Corridors, and projects of national significance with emphasis on intermodal connectors as well as tracking and security technologies including joint ITS intermodal programs; and

- Japan's logistics policy is a "comprehensive" package where all modes participate and contribute, setting quantitative targets and following them up.

Table 12. Major logistics policy measures

\begin{tabular}{l|l}
\hline EU & $\begin{array}{l}\text { Focusing on operations and services } \\
\text { Incentives through subsidies } \\
\text { Pushing technology applications and innovations }\end{array}$ \\
\hline U.S. & Infrastructure oriented, projects of national significance \\
& Co-funding approach and partnerships \\
& Technology applications \\
\hline Japan & "Comprehensive, multi-modal" package within traditional modal budgets \\
& Regulatory reform measures \\
& Pushing technology applications and standardization efforts \\
\hline
\end{tabular}

A somewhat neglected challenge in some logistics policy statements is the issue of intermodal logistics in urban and metropolitan areas (i.e. city logistics with intermodality in mind). Note most freight nodes, distribution centers and intermodal transfer points—-ports, airports, railway terminals - are located in cities, generating important freight flows with impacts in terms of congestion, liveability and pollution. Notable is the case of Chicago where all the major U.S. and Canadian railroads interchange in the urban area, with 1.2 million containers annually moved by trucks over the local road and expressway network. Therefore a substantive intermodal infrastructure and improvement project is now being implemented to improve transhipment, access to facilities and regional distribution.

For intermodal logistics to be efficient, the application of IT systems-ICS and ITS - along the intermodal transport chain is absolutely essential so as to enhance the quality, time reliability and security of intermodal freight services. The information system is the glue that holds the intermodal logistics system together and allows the supply chain to be efficiently managed. Several R\&D projects have been carried out 
in the U.S. and the EU to support smart border facilitation and promote innovative solutions for seamless shipping-port-hinterland operations and freight deliveries, respectively. However, the actual state of practice is still underdeveloped both for tactical intermodal operational management and companies' supply chain planning processes, albeit to a lesser extent in cargo tracking and tracing.

The joint use of a common logistics data base at logistics hubs combined with upto-date intermodal traffic and terminal management schemes could provide substantial improvements especially around Asian ports where port access problems may account for $30 \%$ of total international transport costs. It is likely that the European Marco Polo programme and the American ITS/intermodal freight initiative will stimulate progress in this area.

\section{Intermodal Project Funding}

In the face of the lagging modal shift results, we have found that there is a growing tendency towards multimodal funding for dedicated intermodal infrastructure and missing intermodal links as an overall cost-effective and an environmentally and socially welcome way to go forward.

The U.S. program for intermodal connectors and freight corridors, the EU's intermodal priority infrastructure projects and the French and German policy changes towards multimodal financing from ETC toll collections, point to a changing recognition of the urgency to enhance the long-term functioning of the total multimodal transport system.

What can be said about eligible intermodal projects-The U.S. intermodal connectors and the Marco Polo programmes provide some figures:

- Infrastructure (co)funding for access roads to intermodal terminals and hubs, if road traffic flows are $>100$ trucks/day in each direction or the port has $>50,000$ TEUs/year (U.S. context); and

- With the minimum subsidy set at 0.5 million Euros and a rate of $500 \mathrm{t}-\mathrm{km}$ shifted for 1 Euro subsidy, each individual European modal shift project accepted would move at least 250 million t-km off the road.

At present it is not possible to identify a common thread in project eligibility, since the projects will have different outcomes in the regions concerned and since some constraints, (e.g. financial ones ${ }^{6}$ ) may have a dominating influence.

\footnotetext{
- Note the considerable differences in the respective budget envelopes. The U.S. intermodal connector program, mostly infrastructure oriented, has a planned US $\$ 3$ bn budget in the framework of the next 6 year SAFETEA legislation while Marco Polo, mostly operations oriented, has a 75 million Euros budget for the next three years.
} 


\section{Intermodal Security}

The policies discussed in this paper originated mostly before the September 2001 event. So the intermodal and global security issue, which now dominates many international discussions, is scarcely addressed in the intermodal policy statements referred to. It will play an important role in the new American transportation legislation ('SAFETEA' or also called 'Legacy for Users') to start in 2004.

The effect of these considerations and the measures taken so far by the U.S. on trade facilitation, customs, inspections, productivity, costs, etc is substantial. All modes and the entire supply chain are concerned. While at first sight intermodal logistics is at disadvantage, there are potential supply chain benefits as well. New control and tracking technologies are applied or being tested as are new global trade procedures. It is likely that these will also have an effect on domestic intermodal logistics.

\section{Policy Implementation}

In our market economies cost, transport time and (time) reliability, service quality and environmental criteria will dominate the individual choice of modal or intermodal chain logistics, rather than top-down regulatory management and policy pressure at governmental level.

This is reflected by the rather mixed and often disappointing results of modal shift actions so far. Note the still growing modal share of trucking in Japan or the limited impact of the EU's former PACT incentive programme (1997-99) that achieved just a $1 \%$ modal shift of combined transport. In contrast, due to growing market demand, the domestic intermodal rail share in the U.S. has grown by an annual $5 \%$ for more than a decade.

To widen the constituency of the intermodal logistics sector, joint efforts and coalitions are necessary involving a range of stakeholders. In the U.S., in the U.K. and also in Japan, such initiatives are being undertaken in the form of 'coalitions', involving the logistics industry and local and regional (state, prefecture) governments (e.g. transport and land use planning agencies). The target setting and monitoring approach set in motion in the Japanese decision making process seems to be productive and implementable, also in other national or regional contexts.

As to Asia, there is still much room for working on a common perspective of an efficient intermodal network for container transport between the ports and major inland destinations.

\section{REFERENCES}

AASHTO (2002) Freight-rail Bottom Line Report, Washington, D.C..

AEA Technology Environment (2000), Evaluation of the implementation of Council

Regulation 2196/98 (PACT). Final Report for the EC DG Energy and Transport, Oxon/Brussels, November 2000. 
Asian Task Force (2003), Logistics Developments Supported by ICT and ITS in the Asia -Pacific Region, OECD \& Institute of Highway Economics.

Cambridge Systematics (1999), Challenges and Opportunities for an ITS/Intermodal freight Program, Cambridge.

EC (1997) Combined transport: intermodality of goods transport, Communication from the Commission. COM(97) 243 final, Brussels.

EC (2001) White Paper: European Transport Policy for 2010: Time to Decide, Brussels.

EC (2002) Intermodal transport: The Marco Polo programme. Proposal for granting community financial assistance to improve the environmental performance of the freight transport system, COM(2002) 54 final. Official Journal, Brussels, May.

EC (2003) European Commission promotes Short Sea Shipping and new intermodal equipment to fight congestion, Press release, Brussels, April.

European Parliament (2002) Report on the Commission White Paper, December.

Horn, B. and Nemoto, T (2004) Intermodal Logistics Policies in the EU, the U.S. and Japan, ITPS, Tokyo.

Japanese Government (1997) Comprehensive program of logistics policies, Authorized by Cabinet Meeting.

Japanese Government (2001) New comprehensive program of logistics policies, Authorized by Cabinet Meeting.

Japanese Government (2002) $1^{\text {st }}$ follow-up report of the logistics policies.

Japanese Governmen (2003) $2^{\text {nd }}$ follow-up report of the logistics policies.

Ministry of Land, Transport and Infrastructure (2000) National Freight OD Survey 2000, Japan, March 2002.

Ministry of Transport, Public Works and Water Management (2000) Modal shift project, Hague, The Netherlands. May.

NCHRP (National Cooperative Highway Research Programme) (2003) Financing and improving land access to U.S. intermodal cargo hubs, NCHRP Report 497, TRB. Washington, D.C.

Nemoto, T. (2003) Planning Intermodal Freight Transport System in Asia, Journal of Logistics and Shipping Economics, No 37.

Transport Ecology Mobility Foundations (1999) Report on modal shift model projects.

U.S. DOT. BTS ( Bureau of Transportation Statistics) (2001) North American trade and travel trends, Washington, D.C..

U.S. DOT. FHWA (1995) Intermodal freight transportation: Overview of impediments. Washington, D.C..

U.S. DOT, NHS (2000) intermodal freight connectors: A Report to Congress, Washington, D.C., July. 